Research Article

\title{
Screening of a novel-substituted furan compound for analgesic activity in mice
}

\author{
Nithya Karnam ${ }^{1}$, Jayakumar J.K. ${ }^{2}{ }^{*}$, Supriya ${ }^{3}$, Revanaswamy ${ }^{4}$
}

${ }^{1}$ Department of Pharmacology, G. Melmaruvathur Adhiparasakthi Institute of Medical Sciences and Research, Tamil Nadu - 603319, India ${ }^{2}$ Department of Pharmacology, Sri Devaraj Urs Medical College, Tamaka, Kolar, Karnataka - 563101, India ${ }^{3}$ Department of Pharmacology, Sri Sai Dental College and Research Institute, Shapuram, Srikakulam, Andhra Pradesh, India

${ }^{4}$ Department of Pharmacology, PES Institute of Medical Sciences and Research, Kuppam, Andhra Pradesh 517425, India

Received: 10 August 2016 Accepted: 25 August 2016

*Correspondence to: Dr. Jayakumar J. K., Email: drjkshapur@gmail.com

Copyright: (C) the author(s), publisher and licensee Medip Academy. This is an openaccess article distributed under the terms of the Creative Commons Attribution NonCommercial License, which permits unrestricted noncommercial use, distribution, and reproduction in any medium, provided the original work is properly cited.

\begin{abstract}
Background: Pain is an unpleasant sensation and is the most primitive of all senses. It is a major symptom in many medical conditions and can significantly interfere with a person's quality of life and general functioning. Analgesics like opioids and NSAIDS are used to treat pain but due to their side effects on long term use it is necessary to develop a compound with reduced side effects. Hence the present study was focused on screening of novel compound of novel compound 2-(4-nitrophenylimino)-N-cyclohexyl-4,5 diphenylfuran-3carboxamide (AMSM-2(a-k) for analgesic activity in mice.

Methods: The analgesic activity of test compound AMSM-2(a-k) at different doses $(5 \mathrm{mg} / \mathrm{kg}, 10 \mathrm{mg} / \mathrm{kg}$ and $20 \mathrm{mg} / \mathrm{kg}$ ) was evaluated by using Eddy's hot plate for determining central analgesic activity using morphine $(5 \mathrm{mg} / \mathrm{kg})$ as standard drug, acetic acid induced writhing test for peripheral analgesic activity and formalin induced writhing test to evaluate both central and peripheral analgesic activity using aspirin as standard drug $(300 \mathrm{mg} / \mathrm{kg})$. The percentages of inhibition of writhing's were calculated for acetic acid and formalin induced pain model. The statistical analysis was done using one way ANOVA followed by Dunnett's test. All values with $\mathrm{P}<0.05$ were considered statistically significant.
\end{abstract}

Results: In hot plate method, the percentage increase in the latency of licking for test compound AMSM-2(a-k) at $20 \mathrm{mg} / \mathrm{kg}$ was significantly comparable to standard drug. Morphine (10 mg/kg) and AMSM-2(a-k) $(20 \mathrm{mg} / \mathrm{kg})$ gave the peak effect at 90 minutes. In acetic acid induced writhing method the percentage inhibition for AMSM-2(a-k) $(20 \mathrm{mg} / \mathrm{kg})$ was $73.93 \%$ for up to 20 min and for aspirin was $57.12 \%$. In formalin induced paw licking method, the percentage inhibition in licking response in the early phase for AMSM-2(a-k) with $20 \mathrm{mg} / \mathrm{kg}$ was $63.23 \%$ which was more significant than the standard drug aspirin $(100 \mathrm{mg} / \mathrm{kg})$ which gave a percentage inhibition of $42.17 \%$. In the late phase the percentage inhibition in licking response for AMSM-2(a-k) (20 $\mathrm{mg} / \mathrm{kg}$ ) was $74.33 \%$ and aspirin $(100 \mathrm{mg} / \mathrm{kg})$ gave a percentage inhibition of $60.82 \%$.

Conclusions: The test drug AMSM-2(a-k) at a dose of $20 \mathrm{mg} / \mathrm{kg}$ showed promising results in hot plate method, equally comparable to the standard drug morphine and in acetic acid induced writhing test and formalin induced paw licking (early and late phase) methods they are more significant than the standard drug aspirin. This suggests AMSM-2(a-k) had potential central and peripheral analgesic activity.

Keywords: Morphine, Aspirin, Novel-substituted furan compound, Analgesic activity 


\section{INTRODUCTION}

Pain is an unpleasant sensory and emotional experience associated with actual or potential tissue damage. ${ }^{1}$ It is a part of a defensive reaction against dysfunction of an organ or imbalance in its functions against potentially dangerous stimulus. It is a major symptom in many medical conditions and can significantly interfere with a person's quality of life and general functioning. ${ }^{2}$ Psychological factors such as social support, hypnotic suggestion, excitement or distraction can significantly modulate pain's intensity or unpleasantness. ${ }^{3,4}$ This discomfort of pain can be removed by a group of compounds called analgesics. Opioid analgesics and NSAID's are widely used in the management of pain but these are associated with serious adverse effects such as ulceration, gastrointestinal bleeding, additive potential, respiratory distress, drowsiness, nausea etc. ${ }^{5}$

Based on the above reports, the authors were interested to search some compounds as analgesics with little or no side effects. Hence, the present study was designed to investigate the analgesic activity of novel substituted furan compound 2-(4-nitrophenylimino)-N-cyclohexyl4,5 diphenylfuran-3- carboxamide (AMSM-2(a-k) to treat pains and headaches.

\section{METHODS}

\section{Synthesis of test compound}

The synthetic compound used for screening in the present study was synthesized in the P.E.S College of Pharmacy, Bangalore. The test compound 2-(4-nitrophenylimino)-Ncyclohexyl-4,5 diphenylfuran-3- carboxamide (AMSM2(a-k) was synthesized by using a mixture of 2-amino-Ncyclohexyl-4, 5-diphenylfuran-3-carboxamide (AMSM2) $(0.005 \mathrm{~mol}, 1.045 \mathrm{gm})$, aryl aldehyde $(0.005 \mathrm{~mol})$ in ethanol $(30 \mathrm{ml})$ and catalytic amount of glacial acetic acid (10 ml) as shown in Figure 1. This mixture was irradiated in microwave (900 watt) for $90 \mathrm{Sec}$. Later it was cooled to room temperature and the solid separated was filtered, washed with isopropanol and recrystallized with suitable solvent.

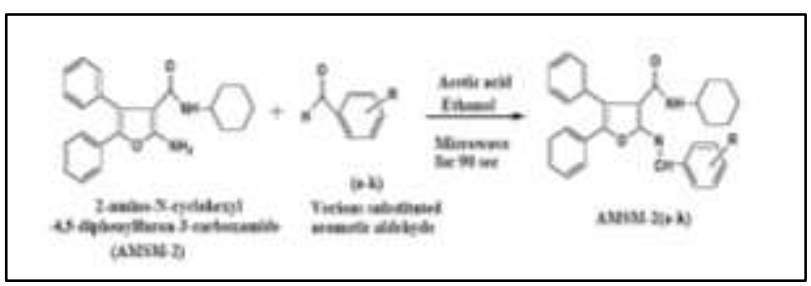

Figure 1: Synthetic scheme for synthesizing the 2-(4nitrophenylimino)-N-cyclohexyl-4,5 diphenylfuran-3carboxamide (AMSM-2(a-k).

Infrared radiation (IR) spectra were recorded for the test compound by potassium bromide $(\mathrm{KBr})$ pellet method. The different frequencies of the test compound were given in Table 1. Melting point of the compound 4nitrobenzaldehyde $=83^{\circ} \mathrm{C}$. The purity of the compound was tested by TLC and Rf value measured was 0.52 .

Table 1: IR spectra of the test compound.

\begin{tabular}{|ll|}
\hline Frequencies & Functional group \\
\hline $3512.49,3433.41$ & $\mathrm{NH}$, str \\
\hline 3076.56 & $\mathrm{CH}$, str \\
\hline $1535.39,1437.02$ & $\mathrm{C}=\mathrm{C}$ \\
\hline 1659.23 & $\mathrm{NH}$, bend \\
\hline 1689.70 & $\mathrm{C}=\mathrm{O}$ \\
\hline 1174.69 & $\mathrm{C}-\mathrm{N}$ \\
\hline 2929.97 & $\mathrm{CH}$, bend \\
\hline 1371.43 & $\mathrm{C}-\mathrm{O}$, str \\
\hline 1633.76 & $\mathrm{CH} 2$ \\
\hline
\end{tabular}

\section{Analgesic activity}

The synthesized test compound was screened for analgesic activity by using the hot plate, acetic acid induced writhing and formalin induced paw licking methods in albino mice.

\section{Animals}

Swiss albino mice of either sex (20-25 g) were selected and maintained for 7 days in the animal house under standard conditions: temperature $\left(24 \pm 10^{\circ} \mathrm{C}\right)$, relative humidity (45-55\%) and 12:12 light: dark cycle. The animals were fed with standard rat pellet and water ad libitum. The animals were allowed to acclimatize to laboratory conditions 48 hours before the start of the experiment. All the experiments were conducted after obtaining permission from the Institutional Animal Ethics Committee (IAEC). For three methods a total of 90 mice were selected. For each test 30 mice were included and divided into 5 groups each consisting of 6 mice.

\section{Hot plate (Eddy's hot plate) test}

In this method control animals were orally administered with $10 \%$ tween 80 , standard group received morphine 5 $\mathrm{mg} / \mathrm{kg}$ intraperitoneally and remaining three groups received test compound orally at a doses of $5 \mathrm{mg} / \mathrm{kg}, 10$ $\mathrm{mg} / \mathrm{kg}$ and $20 \mathrm{mg} / \mathrm{kg}$ by suspending in $10 \%$ tween 80 respectively. After $60 \mathrm{~min}$ of the administration of tween 80 , morphine and test compound the time (reaction time) it takes each of the animals to jump off the hot plate was noted at the intervals of 20,60 and $90 \mathrm{~min}$ and cut off period was 15 second. The mean of the responses for the animals (6 per group) administered each compound was compared with the control group.

\section{Acetic acid induced writhing method}

Mice were divided into 5 groups consisting 6 animals in each. All the animals were pre-treated with aspirin (100 $\mathrm{mg} / \mathrm{kg}$, p.o $)$, as standard drug, test compound $(5 \mathrm{mg} / \mathrm{kg}$; 
$10 \mathrm{mg} / \mathrm{kg} ; 20 \mathrm{mg} / \mathrm{kg}$ ) was administered orally. After one hour of drug administration $1 \%$ acetic acid was injected intra peritoneally. 5 minutes after the intraperitoneal injection of acetic acid, number of writhes was counted in individual mice for a period of 20 minutes. The mean value for each group was calculated and compared with the control and percentage inhibition of analgesic activity was calculated using the formula. ${ }^{7}$

$\%$ Inhibition $=(\mathrm{Nc}-\mathrm{Nt} / \mathrm{Nc}) \times 100$

Where; Nt and $\mathrm{Nc}$ are the mean values of number of writhing in the test and control group, respectively.

\section{Formalin induced writhing test}

In this study, mice were injected orally with aspirin or test drug. One hour later each mouse was administered $0.1 \mathrm{ml}$ of $1 \%$ formalin subcutaneously under the dorsal surface of the hind paw. Each individual mouse was observed for a licking response. Readings were taken at 0-5 minutes and 20-30 minutes. Pain responses were indicated by elevation or favouring of the paw or excessive licking and biting of the paw. Analgesic response or protection was indicated if both paws were resting on the floor with no obvious favouring of the injected paw. The mean for each group was determined and compared with the control group and the percentage inhibition against formalin induced paw licking in mice was calculated. ${ }^{8}$

$\%$ inhibition $=(\mathrm{Nc}-\mathrm{Nt} / \mathrm{Nc}) \times 100$

Where; Nt and Nc are the mean values of number of writhing in the test and control group, respectively.

\section{Statistical analysis}

All the results were analysed by one-way ANOVA followed by the Dunnett's test. Values are expressed as mean \pm SD and percentages. The probability of 0.05 or less was considered statistically significant.

\section{RESULTS}

\section{Hot plate method}

The onset of licking response in mice at different time intervals in seconds for the standard drug morphine and test drug (AMSM-2(a-k) $(5 \mathrm{mg} / \mathrm{kg} ; 10 \mathrm{mg} / \mathrm{kg} ; 20 \mathrm{mg} / \mathrm{kg}$ ), tween 80 for control group were calculated and presented in Table 2. It was observed that AMSM-2(a-k) at high dose $(20 \mathrm{mg} / \mathrm{kg})$ had attained peak effect at 90 minutes time when compared to control.

Table 2: Effect of AMSM-2(a-k) on latency time in seconds at different time intervals in hot plate method.

\begin{tabular}{|lllll|}
\hline \multirow{2}{*}{ Treatment } & \multicolumn{3}{c|}{ Latency time (in sec) at different time intervals } \\
\hline Control & $\mathbf{0}$ min & $\mathbf{2 0}$ min & $\mathbf{6 0}$ min & $\mathbf{9 0}$ min \\
\hline Standard (morphine $5 \mathrm{mg} / \mathrm{kg})$ & $3.20 \pm 0.86$ & $3.51 \pm 0.44$ & $3.62 \pm 0.57$ & $4.29 \pm 0.50$ \\
\hline Low dose (AMSM-2(a-k) $(5 \mathrm{mg} / \mathrm{kg})$ & $3.52 \pm 0.83^{\mathrm{ns}}$ & $7.03 \pm 1.01^{*}$ & $7.34 \pm 1.63^{*}$ & $7.43 \pm 1^{*}$ \\
\hline Medium dose (AMSM-2(a-k) $(10 \mathrm{mg} / \mathrm{kg})$ & $4.02 \pm 0.69^{\mathrm{ns}}$ & $5.72 \pm 0.97^{*}$ & $6.30 \pm 0.48^{*}$ & $7.03 \pm 0.73^{*}$ \\
\hline High dose (AMSM-2(a-k) $(20 \mathrm{mg} / \mathrm{kg})$ & $4.1 \pm 0.74^{\mathrm{ns}}$ & $6.33 \pm 0.69^{*}$ & $6.72 \pm 0.564^{*}$ & $7.21 \pm 1.10^{*}$ \\
\hline
\end{tabular}

Values are expressed as mean \pm SD. $*=P<0.001$ compared with control group. ns $=$ not significant.

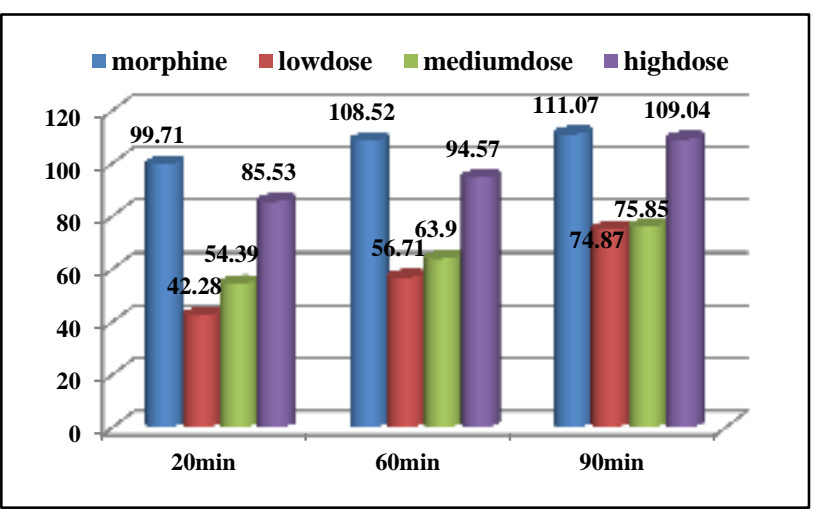

Figure 2: Effect of AMSM-2(a-k) on percentage latency time for licking response in mice.
The percentage increase in latency time for licking response in mice at different time intervals were given in Figure 2.

Acetic acid induced writhing test

The results were shown in Table 3. Numbers of writhing's observed for $20 \mathrm{~min}$. It was observed test drug produced dose dependent inhibition of writhing behaviour. The writhing counts decreased significantly in the group treated with highest dose $(20 \mathrm{mg} / \mathrm{kg})$ of AMSM-2(a-k) to about $73.93 \%$ which was comparable to standard drug morphine having $57.12 \%$. The groups treated with test drug with different doses $(5 \mathrm{mg} / \mathrm{kg}$ and $10 \mathrm{mg} / \mathrm{kg}$ ) also showed significant reduction in writhing 
due to acetic acid when compared and the percentage of

inhibition being $46 \%$ and $66.7 \%$ respectively in Table 3 .

Table 3: Effect of AMSM-2(a-k) on acetic acid induced writhing test in mice.

\begin{tabular}{|llll|}
\hline Treatment & Number of writhing (counts/20 min) & \% inhibition & P value \\
\hline Control & $90.16 \pm 3.48$ & - & \\
\hline Standard (aspirin $300 \mathrm{mg} / \mathrm{kg})$ & $38.66 \pm 3.26^{* *}$ & 57.12 & 0.001 \\
\hline Low dose (AMSM-2(a-k) $(5 \mathrm{mg} / \mathrm{kg})$ & $48.66 \pm 7.06^{*}$ & 46.02 & 0.01 \\
\hline Medium dose (AMSM-2(a-k) $(10 \mathrm{mg} / \mathrm{kg})$ & $30 \pm 3.84^{* *}$ & 66.72 & 0.001 \\
\hline High dose (AMSM-2(a-k) $(20 \mathrm{mg} / \mathrm{kg})$ & $23.50 \pm 3.08^{* *}$ & 73.93 & 0.001 \\
\hline
\end{tabular}

\section{Formalin induced paw licking method}

The paw licking phases were divided into two phases. Early phase was observed for $0-15 \mathrm{~min}$ and late phase was observed for 20-30 min. In both the phases the group of animal treated with higher doses of AMSM-2(a-k) 20 $\mathrm{mg} / \mathrm{kg}$ produced significant reduction in episodes of licking with percentage of inhibition 63.2 and 74.3 respectively when compared. The group received morphine produced significant percentage inhibition at late phase $60 \%$. The other test groups $5 \mathrm{mg} / \mathrm{kg}$ and 10 $\mathrm{mg} / \mathrm{kg}$ also showed significant percentage inhibition in late phase 47 and 62 than early phase 40 and 57 respectively as shown in Table 4 . These results suggests test drug possess significant analgesic activity at late phase against formalin induced paw licking in mice.

Table 4: Effect of AMSM-2(a-k) on formalin induced paw licking model in mice.

\begin{tabular}{|llllll|}
\hline Treatment & Early phase $(\mathbf{0}-\mathbf{1 5} \mathbf{~ m i n})$ & Late phase $(\mathbf{2 0 - 3 0} \mathbf{~ m i n})$ & \multicolumn{2}{l|}{ Percentage inhibition } & P value \\
\hline Control & $34 \pm 3.09$ & $24.66 \pm 2.16$ & - & - & - \\
\hline $\begin{array}{l}\text { Standard (aspirin } 300 \\
\text { mg/kg) }\end{array}$ & $21 \pm 4.56^{* *}$ & $9.66 \pm 1.21^{* *}$ & 42.17 & 60.82 & 0.001 \\
\hline $\begin{array}{l}\text { Low dose(AMSM-2(a-k) } \\
(5 \mathrm{mg} / \mathrm{kg})\end{array}$ & $20.33 \pm 2.42^{*}$ & $13 \pm 1.78^{*}$ & 40.20 & 47.28 & 0.01 \\
\hline $\begin{array}{l}\text { Medium dose (AMSM-2 } \\
\text { (a-k) }(10 \mathrm{mg} / \mathrm{kg})\end{array}$ & $14.33 \pm 2.58^{* *}$ & $9.33 \pm 4.08^{* *}$ & 57.85 & 62.16 & 0.001 \\
\hline $\begin{array}{l}\text { High dose (AMSM-2 } \\
(\mathrm{a}-\mathrm{k})(20 \mathrm{mg} / \mathrm{kg})\end{array}$ & $12.50 \pm 1.87^{* *}$ & $6.33 \pm 1.63^{* *}$ & 63.23 & 74.33 & 0.001 \\
\hline
\end{tabular}

\section{DISCUSSION}

The results obtained from the present study shows that the novel test compound 2-(4-nitrophenylimino)-Ncyclohexyl-4,5 diphenylfuran-3- carboxamide (AMSM-2 (a-k) has analgesic activity.

In the present study acetic acid induced writhing test was performed to determine the peripheral analgesic activity of AMSM-2 (a-k). The standard drug used was aspirin as analgesic by exerting its effect primarily by interfering with the biosynthesis of cyclic prostanoids, i.e, thromboxane A2 (TXA2), prostacyclin, and other prostaglandins. ${ }^{9}$ The acetic acid induced writhing test is a standard test for measuring peripheral analgesic activity for novel analgesics. ${ }^{10}$ The associated pain response in this model is believed to involve the release of endogenous substances such as bradykinin and prostanoids, among others, which stimulate the nociceptive endings. ${ }^{11}$ In this study, from the results it was evident that the test compound AMSM-2(a-k) showed significant analgesic effect than aspirin.

The formalin test in mice has been proposed as a chronic pain model which is sensitive to both peripheral and centrally active analgesic agents. The analgesic activity was estimated in two phases. The early phase of pain is attributed to the direct activation of nociceptors and primary afferent fibers by formalin, causing the release of pain mediators like tachykinins and bradykinin. ${ }^{12,13}$ This phase is inhibited by opioid analgesics. ${ }^{14}$ The second phase is due to an inflammatory reaction caused by tissue injury leading to the release of histamine, serotonin, prostaglandin, and excitatory amino acids. ${ }^{15,16}$ This phase is inhibited by non-steroidal, anti-inflammatory drugs (NSAIDs) and opioid analgesics. From the results it was 
observed that AMSM-2(a-k) produced dose dependent inhibition in paw licking in mice in both phases. This indicated the novel compound AMSM-2(a-k) has both opioid analgesic and NSAID action.

Hot plate method is a sensitive model to evaluate central analgesic activity. The paws of mice are very sensitive to heat at temperature which does not damage the skin. Responses found in this test are jumping, withdrawal of the paws and licking of the paws. ${ }^{17}$ The test drug at all doses prolonged reaction time. Of all high dose of AMSM-2(a-k) (20 mg/kg) showed potent analgesic activity at 90 minutes than standard drug morphine suggesting it had potent opioid receptor inhibition.

\section{CONCLUSION}

This investigation can conclude that the novel substituted furan compound possesses significant analgesic activity. The mechanism may involve both central and peripheral mechanisms. More number of tests has to be performed using more number of animals and different species to confirm the claim of analgesic activity for this novel substituted furan compound.

Funding: No funding sources Conflict of interest: None declared

Ethical approval: The study was approved by the Institutional Ethics Committee

\section{REFERENCES}

1. Bonica JJ. Derived: International association for the study of pain: pain definitions. Pain is an unpleasant sensory and emotional experience associated with actual or potential tissue damage, or described in terms of such damage. The need of taxonomy. Pain. 1979;6(3):247-8.

2. Merskey H, Bogduk N. Classification of chronic pain. $2^{\text {nd }}$ edition. Seattle: International Association for the Study of Pain press; 1994:3-4.

3. Woolf CJ, Bennett GJ, Doherty M, Dubner R, Kidd B, Koltzenburg M, et al. Towards a mechanismbased classification of pain? Pain. 1998;77(3):227-9.

4. Woolf CJ. What is this thing called pain? J of Clin Invest. 2010;120(11):3742-4.
5. Laurence DR, Benneth PN, Brown MJ. Clinical Pharmacology. $8^{\text {th }}$ edn. Edinburgh: ChurchHill Livingstone; 1997.

6. Eddy NB, Leimbach D. Synthetic analgesics: II. Dithenylbutenyl and dithienyl-butylamines. J Pharmacol Exp Ther. 1953;107:385-93.

7. Hunskaar HS, Fasmer OB, Hole K. Formalin test in mice, a useful technique for evaluating mild analgesics. J Neurosci Methods. 1985;14:69-7.

8. Dubuisson D, Dennis SG. The formalin test: a quantitative study of the analgesic effects of morphine, meperidine and brain stem stimulation in rats and cats. Pain. 1977;4:161-74.

9. Vane JR, Bakhle YS, Botting RM. Cyclooxygenases 1 and 2. Ann Rev Pharmacol Toxicol. 1998;38:97120.

10. Siegmund E, Cadnus R, Lu G. A method for evaluating both non-narcotic and narcotic analgesics. Proc Soc Exp Biol. 1957;95:729-31.

11. BerkenKopf JW, Weichmann BM. Production of prostacyclin in mice following intraperitoneal injection of acetic acid, phenylbenzoquinone and zymosan: Its role in the writhing response. Prostaglandins. 1988;36:693-709.

12. Shibate M, Ohkubo T, Takashi H, Inoki R. Modified formalin test. Pain. 1989;38:345-52.

13. Correa CR, Calixto JB. Evidence for participation of $\mathrm{B} 1$ and B2 kinin receptors in formalin-induced nociceptive response in the mouse. Br J Pharmacol. 1993;110:193-8.

14. Correa CR, Kyle DJ, Charkraverty S, Calixto JB. Antinociceptive profile of pseudopeptide B2 bradykinin receptor antagonist NPC 18688 in mice. Br J Pharmacol. 1996;117:552-8.

15. Coderre TJ, Melzack R. The contribution of excitatory amino acids to centrall sensitization and persistent nociception after formalin-induced tissue injury. J Neurosci. 1992;12:3665-70.

16. Damas J, Liegeois JF. The inflammatory reaction induced by formalin in the rat paw. Naunyn Schneidebergs Arch Pharmacol. 1999;359:200.

17. Bhakthavatsalam P, Kamatchi GL, Ghosh MN. Dissociation of receptor sensitivity changes in rat perifornical hypothalamus: a role for dopaminergic receptors in amphetamine anorexic tolerance. J Pharmacol Exp Ther. 1987;240:196-202.

Cite this article as: Karnam N, Jayakumar JK, Supriya, Revanaswamy A. Screening of a novelsubstituted furan compound for analgesic activity in mice. Int J Basic Clin Pharmacol 2016;5:1759-63. 